\title{
生活史的視点からのランドスケープ研究
}

\section{Landscape Studies based on the Analysis of Life History}

若生 謙二* Kenji WAKO

\section{1.はじめに}

ランドスケープ研究は領域の拡大にともない, さまざま な視点からのアプローチが必要とされるようになっている。 ランドスケープ研究の主要な対象の一つである公園の研究 では, 近年の新しい傾向として生活史的視点からの研究が 始められている。それは明治以来 120 年をこえる年月の間 に，市民との関係をもちながら社会に定着してきた公園の 歴史性を評価し, 都市における生活文化としての公園の姿 を明らかにしようとするむのである。その研究的蓄積は, 市民のための公園づくりの計画と管理につながるものであ るが, 生活史という言葉の意味のつかみにくさのために, 生活史的視点からの公園研究の意義と方法は, まだ十分に 理解されるに至っていないというのが実情であろう。その ため,ここでは生活史の意味と生活研究のはじまりである 考現学の位置づけをふまえて, 生活史的視点からの公園研 究の方法の枠組みと具体的な研究の展開について述べるこ とにしたい。

\section{2. 方法の枠組み}

生活史研究においては, 生活史という言葉は日本語の一 般的な意味での生活の歴史と個人の生活史という2つの意 味で使われている。そのため生活史研究ではこれらの $2 つ$ の側面からの研究が行われている ${ }^{1)}$ 。現代に連なる生活研 究は今和次郎の考現学にさかのぼることができるが, 彼の 考現学は現代に営まれている生活事象の直接観察とそれら の総体観察の視点に特徴がある。彼はしばしば公園を対象 としてとりあげ，「各公園散策者男女の組の具合」「井の頭 公園春のピクニック」「井の頭公園自殺場所分布図」 ${ }^{2)}$ どの調查を行っている。

考現学は生活研究の原型をなすすのであるため, 生活史 的視点からの公園研究を考える際には, 考現学とその周辺 分野の関係に目を向けることが適切であろう。梅棹は考現 学の方法を既存の他領域との関係から明解に位置づけてい る ${ }^{3)}$ 。民族学が末開社会を冷静に客観的に観察し記述する
ように，考現学は文明社会を客観的に観察し記述する。そ の意味で民族学は未開社会の考現学であり, 考現学は文明 社会の民族学である。また, 民族学に近い民俗学は, 過去 の風俗を現在の残存事象を材料にして研究するものである ため, 現在の事象のなかでもまさに消滅しようとする事象 に特に注意があつまる。それに対し考現学は現在の風俗を 研究するため, 過去からの残存事象をふくめて現在みられ る事象のすべてを材料とする。その意味で民俗学は歴史風 俗学であり, 考現学は現代風俗学であると述べている。

さらに梅棹 ${ }^{3)}$ は, 生活事象の研究に資料として採用でき るあのに文書, 談話, 観察された事実の 3 つの種類があり, 通常, 歴史学では文書だけが信頼できる材料として使われ るが，民俗学では文字に書かれたことのない常民の歴史を 口述の資料にもとづいて再構成することが特徴であると述 べている。それに対して考現学は現代を対象とするため, 直接観察の事実が中心となり, 今日の生態学に近いむので あることを指摘している。生活史的視点からの公園研究で は,これら 3 つすべての資料を用いる方法が可能である。 以上のことから生活史的視点からの公園研究をとらえる と，それは次の 3 つに大別される。

第 1 点は, 公園自体の歴史を生活史的視点からとらえる ことであり，ここには公園と人間生活の関係の歴史という 側面之公園自身の生活史という2つの側面がある。公園と 人間生活の関係をむすぶものは利用であるが, 公園は利用 の変遷によって計画や管理に影響が及び公園の形態にも変 容が生じる。これらの媒介となるのが公園についての見方 や考え方としての公園観である。したがって, 生活史的視 点からの公園史研究では, 利用の姿と人々の公園観に注目 して公園史をとらえることに重点がおかれる。さらに公園 自身の生活史という点では, これらの歴史からステージや 様式をとらえることが課題となる。ここでは公園の利用や 公園に対する意見について書かれた新聞などの文書が有力 な資料になり，口述の資料も用いられる。

第 2 点は, 人間生活の場としての公園の姿を明らかにす

*大阪芸術大学芸術学部 
る公園利用の生活学的研究である。これは直接観察や総体 観察など考現学的な手法によって行われるものであり, 行 動観察が主な対象になる。利用行動を再構成するためには, 公園における生活誌（モノグラフ）の作成も有効な方法で ある。ある意図にあとづいて造成された公園での利用行動 は限定されたものであり, 公園利用の潜在的な行動を抽出 するためには, 野外空間一般での行動む対象とされる。

第 3 点は, 個人の生活史における公園利用の記憶にもと づく利用行動之公園観の分析である。公園観は公園の利用 とその認識によって形成されるため，人々の思い出の中に ある公園像の集積に注目する必要がある。それには，でき るだけ多くの公園利用の記憶を収集することが必要である。 したがって，これには文字の記録や直接観察の記録ととも に，口述の資料にもとづいて生活の中での公園利用の様子 を再構成することが必要とされ，手紙，日記，自伝などあ 有効な資料となりうる。これには特定の公園を対象として それに対する人々の利用行動や公園観を分析するあのと， 公園を利用する生活の全般を対象とするあのに分けること ができる。

\section{3. 研究の展開}

公園生活史の研究は，以下のように進められている。生 活史的視点からの公園史研究には, 進士ら ${ }^{45567)}$ の一連の研 究がみられる。進士らは横浜公園と日比谷公園の生活史年 表を作成し，これらの公園では単なる緑の都市施設，花や 噴水の美しい空間といったイメージをこえた，外交，戦争 などの人間史的・時代史的出来事を反映する生活史的側面 が見い出される と文とし，破壊期に向かいつつあるようにと らえられる公園にかつては「市民利用充実期」があったこ とを指摘している ${ }^{6)}$ 。また，震災復興公園を生活史的視点 からとりあげてその全体像を明らかにした上で, 開園後数

\section{主要文献}

1) 有末 賢 (1984): 生活研究とライフ・ヒストリー : 川添 登編, 生活学へのアプローチ, 49-52, ドメス出版

2 ) 今和次郎・吉田謙吉編著 (1930): モデルノロジオ・考現学, 春陽堂, 考現学今和次郎集第 1 巻所収, $277-284,291-301$ (1971)，ドメス出版

3 ) 梅棹忠夫 (1971) : 考現学と世相史 (上) 一現代史研究への 人類学的アプローチ: 季刊人類学第 2 巻 1 号, 87-119, 社 会思想社

4 ) 進士五十八・増田茂樹 (1982) : 公園生活史の研究 (一), 横 浜公園にみる生活史的考察 : 生活学会報 $9(1), 24-26$

5 ) 進士五十八 (1982) : 公園生活史の研究 (二), 日比谷公園に みる生活史的考察 : 生活学会報 $9(4), 19-25$

6 ）進士五十八 (1983)：公園生活史の研究（三), 比較公園によ る生活史的考察 : 生活学会報 $10(3), 37-41$

7 ) 進士五十八・吉田恵子 (1989) : 震災復興公園の生活史的研
年で不良とルンペンの巣となった公園の生活史を明らかに している7。

公園利用の生活学的研究には, 進士・鈴木らの日比谷公 園の総合的研究 ${ }^{8}$ や長山 ${ }^{9}$ の研究がみられる。進士らは 24 時間の利用実態調查を行い, 日比谷公園では 21 時をピー クとする夜間のアベック利用が特徴的であることを示して いる。これまでの公園利用調查では昼間の利用に対象が限 定されていたが，24時間調查により利用者行動の全体像 が明らかにされ，公園利用についての視点が広げられた。 さらに公園内の利用者の行動追跡加ら利用行動の分類之行 動量の集計を行い，利用者行動と単位空間の総合的分析を 行っている。また, 公園内浮浪者の生態と分布を明らかに しているが，公園におけるこれらの逸脱行為を評価するこ とは, 公園生活史研究の課題である。長山 ${ }^{9)}$ は羽根木プレ イパークにおける利用者の分布調查と追跡調查などの行動 調査を行い，その利用実態を明らかにしている。ニューヨー クのセントラルパークの復元の報告 ${ }^{10)}$ では, 公園の生活史 ととあに公園利用者の生活学的な調査が行われており, 行 動調查をもとにした公園の生活誌の記述による利用行動の 再構成がなされている。

個人の生活史における公園利用の記憶に基づく公園生活 史の研究には若生 ${ }^{11}$ の個人史と公園のとりくみがある。ま

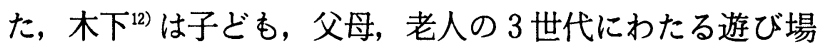
の体験についての聞き取り調查を行い, 鳥瞰的, 猫瞰的, 虫瞰的という 3 つのスケールからその变化を分析している。

本文では公園を対象とした生活史的視点からの研究につ いて述べたが，都市と市民にとっての歷史を評価してまち づくりの中に生かそうとするこれらの視点と方法は, 地域 計画や都市計画など広くランドスケープ全体の研究に応用 することができるものである。

究: 造園雑誌 52(3), 155-165

8 ）進士五十八・鈴木 誠他（1983）：日比谷公園の総合的研究 （1－8）日本建築学会関東支部研究報告集 145-176

9 ) 長山宗美 (1991) : 冒険遊び場（羽根木プレイパーク）の行 動調査からみた利用実態について：造園雑誌 54(5)，347352

10) Elizabeth Barlow Rogers (1987): Rebuilding Central Park - A Management and Restoration Plan: The MIT Press 訳) 龟山 章・監修/若生謙二・訳（1994）： よみがえるセントラルパーク，ソフトサイェンス社

11）若生謙二（1994）: 生活史的視点加らの公園研究一個人史之 公園一について : 日本造園学会関西支部大会発表要旨, 11 12

12）木下 勇 (1986): 三軒茶屋周辺における子どもの遊び場一 その三世代の変遷 : 中鉢正美編著, 生活学の方法, 114-134, ドメス出版 